\title{
Fixation of the Pupae of Selected Butterfly Species and Factors Affecting their Emerging
}

\author{
Mária Babošová*, Martina Perečková, Jana Ivanič Porhajašová \\ Department of Environmentalism and Biology, Faculty of Agrobiology and Food Resources, \\ Slovak University of Agriculture in Nitra, Tr. A. Hlinku 2, 94976 Nitra, Slovakia
}

Received: 6 March 2020

Accepted: 29 June 2020

\begin{abstract}
When breeding butterflies in captivity, it is important to focus on rearing facilities, the choice of healthy population, and the care for the chrysalises. One of the main factors that determine how a butterfly emerges is the fixation of its chrysalis. The study of the butterfly life cycle and emergence from chrysalis was conducted on three butterfly species - the giant owl (Caligo memnon), the common morpho (Morpho peleides), and the indian oakleaf (Kallima inachus), which were the most commercially available species at the time. The aim was to determine the most appropriate type of butterfly chrysalis fixation that would yield the best results with the emergence of the highest numbers of viable imagoes for future breeding in captive conditions. The results of four different types of fixations of the selected butterfly species were compared with each other, and with results obtained from other institutions that breed butterflies.
\end{abstract}

Keywords: chrysalis, butterfly, Caligo memnon, Morpho peleides, Kallima inachus

\section{Introduction}

Butterflies have a typical four stage insect life cycle. Winged adults lay eggs onto their host plants, where their larvae will feed. The caterpillars grow, sometimes very rapidly, and when fully developed they pupate into a chrysalis. When metamorphosis is complete the pupal skin splits and the imago climbs out. After its wings have expanded, and dried off, it flies away $[1,2]$. Butterflies are a very old and diverse order of insects [3, 4]. Within the order, there is both high phenotypic and genotypic variability associated with the specifics of each individual species. All the species differ from one another with different body dimensions, size and wing structures, protective coloring, habitat, bionomy, length of life cycles, food bases, behavior, diurnal, crepuscular or nocturnal activity [5]. Within the species, many subspecies are known with varying demands on the environment, altitude, sunlight and host plants. Subspecies often crossbreed, and create fertile hybrids, so it can be very difficult to determine them taxonomically [6]. Crossbreeding between different species is not common in the wild. It usually occurs in captive breeding conditions, and the hybrids are infertile [7, 8]. Free-flying butterflies in purpose built exhibits have become more and more popular in zoo collections all over the world [9, 10]. Exhibitions of live butterflies can have high educational potential [11, 12]. It also helps with their conservation in nature [13].

*e-mail: Maria.Babosova@uniag.sk 


\section{Materials and Methods}

The research was carried out from June $7^{\text {th }}, 2017$ from the delivery and fixation of the first shipment of chrysalises, until August 31 ${ }^{\text {st }}$, 2017, when the last imagoes emerged. Butterfly chrysalises were imported from a butterfly farm located in Stratford Upon Avon, England. Due to the high diversity of butterfly species, the research was carried out on the three most accessible and most frequently bred species. Throughout the experiment 684 chrysalises of the giant owl (Caligo memnon), 754 chrysalises of the common morpho (Morpho peleides) and 200 chrysalises of the indian oakleaf (Kallima inachus) were used. The total number of chrysalises of all three species was 1638 . The rearing facility was disinfected with vinegar before every new shipment arrived.

Fixation of butterfly chrysalises was carried out in butterfly garden with an area of $1200 \mathrm{~m}^{2}$, where the breeding and the rearing facilities were located. In the rearing section the monitored microclimatic indicators were temperature and humidity. The intensity of the lighting, air flow and air exchange had no effect on the chrysalises, so they were monitored only in the breeding area where only imagoes were present, the floor of was covered with linoleum and the walls were made of plastic mesh with a diameter of $5 \mathrm{~mm}$.

\section{Chrysalis Transportation}

The chrysalises, imported from England, were in stage of development, so they would start to emerge approximately 48 hours after they arrived. Earlier hatching would cause the hatched butterflies to die during transport. The travel box was made of polystyrene, and it was lined with cotton wool. The chrysalises were placed side by side, insulated from each other by the wool, which protected them from any damage. The quality of the shipment was determined by the speed of delivery. The temperature of the external environment affected the development in the chrysalis, the lower the temperature, the more the time until the emerging began, in cases when the weather was too hot they would include a cooling patch in each transport box. The shipments arrived once a week.

\section{Rearing Facility}

The size of the rearing facility was $18 \mathrm{~m}^{2}(6 \mathrm{~m}$ long, $3 \mathrm{~m}$ wide and $2.5 \mathrm{~m}$ high) (Fig. 1). It provided suitable conditions for rearing chrysalises from their fixation to emerging. The facility walls were made of horticultural foil. The rearing and emerging itself was realized in four separate shower boxes inside this facility, with an area of 0.64 to $0.81 \mathrm{~m}^{2}$ and a height of $2 \mathrm{~m}$ each, which had Plexiglas walls and glass doors. The top and bottom parts were covered with linoleum. About $30 \mathrm{~cm}$ above the floor was a plastic fine wire mesh that caught butterflies, which were not able to hold on to the slat or pupal skin after emerging. It also prevented them from sticking to the wet floor after falling down. Back walls of each shower box were equipped with metal holders that held $30 \mathrm{~cm}$ long wooden slats, and there were either 19 slats $4 \mathrm{~cm}$ apart or 10 slats $8 \mathrm{~cm}$ apart. The highest slat was $18 \mathrm{~cm}$ from the ceiling. The glass doors were open during the day, closed at night to maintain the necessary humidity. The chrysalises were fixed to the slats using latex-based rubber cement.

\section{Microclimate of the Rearing Facility}

The most important factors affecting the health of chrysalises in the rearing facility were temperature and humidity. Therefore, the shower boxes were equipped with temperature and humidity meters, and the floor was covered with cotton, which helped to maintain the moisture, prevented water accumulation, and spreading of mold. There was a rule that the temperatures in the facility could not exceed $28^{\circ} \mathrm{C}$ and the humidity could not fall below $50 \%$. In the morning, the average temperature in the rearing facility was kept between 24.5 and $25.5^{\circ} \mathrm{C}$ and the average humidity was between 74.5 and $75.5 \%$. There was an additional heat source in case we needed to raise the desired temperature. If the temperature or humidity got higher, it was vented out by opening the rearing facilities entrance door. At lower humidity levels the entire rearing facility, including the shower box interiors, was sprayed with water. At noon the temperature rose to $26-27^{\circ} \mathrm{C}$ while the humidity dropped to $63-64 \%$. In the evening, the temperature

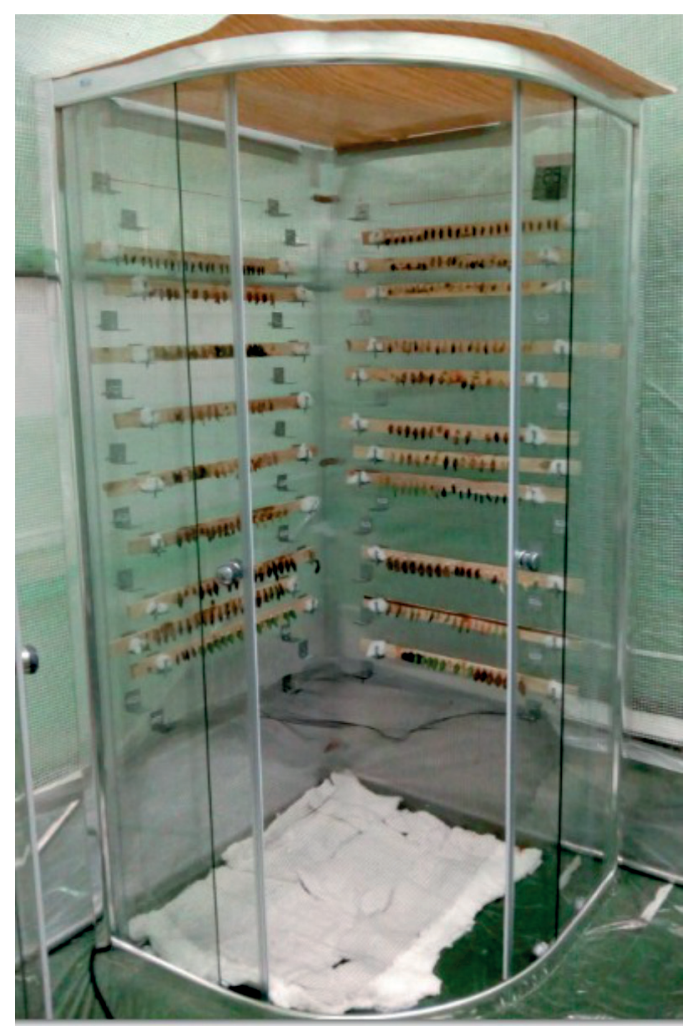

Fig. 1. Rearing Facility. 
was kept similar to the noon temperature or $0.5^{\circ} \mathrm{C}$ higher and the humidity increased to $65-68.5 \%$. The butterfly imagoes were emerging from 6:00 until 17:00.

\section{Methods of Fixation and Chrysalis Care}

As soon as the chrysalises were received, they were fixed onto slats and placed inside a shower box to acclimatize to the temperature and humidity needed for normal development. The chrysalises were glued to wooden slats using Copydex, a natural latex based cement. A small drop of glue was applied directly onto a slat and the chrysalis was attached by the cremaster, which attaches the chrysalis to the plant in nature. It was necessary to consider which end of the chrysalis was the head and which was the cremaster. Since the head part was where the butterfly would start to emerge, in case it got glued up, the butterfly would die trying to emerge. The chrysalises are sensitive to touch and move their abdomen when handled, so it was better to let the glue drops dry a little before submerging the cremaster into it. Four types of fixing were tested during the experiment (Fig. 2):

1. Upper fixation - dense - chrysalises were glued to the upper part of the wooden slat, close to each other, with a gap of 0.5 to $1 \mathrm{~cm}$ between them.

2. Upper fixation - sparse - chrysalises were glued to the upper of the slat, as in the first case, with a gap of $2-2.5 \mathrm{~cm}$ between them.

3. Lower fixation - dense - chrysalises were glued to the lower part of the slat so they would hang from it. The distance between individuals was, as in the upper dense fixation, as small as possible from 0.5 to $1 \mathrm{~cm}$ gap between them, depending on the size of the chrysalises (smaller chrysalises, like those of Kallima inachus, were placed closer together, than those of the larger species).

4. Lower fixation - sparse - chrysalises were glued to the lower part of the slat, further apart from each other with 2 to $2.5 \mathrm{~cm}$ gap between them. This method was the closest simulation of the natural conditions, where the chrysalis hangs from a plant and has enough space around it.

The chrysalis care included daily checkups. A healthy chrysalis is firm, flexible, with no change in coloration and no discharge. In a vitality test, the chrysalises were gently sprayed with water. Healthy chrysalises would move after water drops touched them. When a chrysalis softened, darkened and did not move at all, it meant that it had most likely died and it had to be removed immediately to prevent any transfer of bacteria to neighboring chrysalises.

\section{Emerging}

Before emerging the chrysalis walls became translucent. The head part split open as the imago started to crawl out. The first butterflies started emerging 24 48 hours after chrysalises were placed into the shower

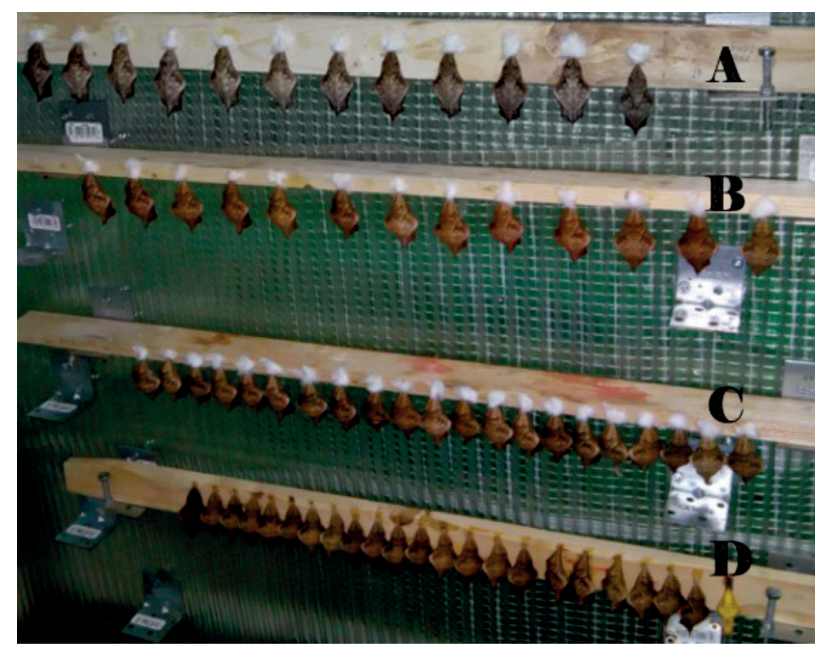

Fig. 2. Methods of fixing Caligo memmon chrysalises: A upper sparse fixation, B - lower sparse fixation, C - lower dense fixation, D - upper dense fixation.

boxes, and most of them usually emerged within 7 days. Many of the unemerged chrysalises, after the 7 day period, were most likely dead. After leaving a chrysalis, an imago hooked its legs onto a wooden slat or its pupal walls and rested, pumping its wings with lymph from its abdomen and waiting for them to dry up. If, during this time, it came into contact with another butterfly or fell down, its wings would most likely tear, the lymph would leak through the holes and droplets of it would start forming on wings. These damaged butterflies were no longer able to fly because their wings never straightened. To avoid this, the imagoes were removed from the hatchery and were hung on ropes in the breeding facility. If the imago was well developed and strong enough, it managed to keep itself hanging from the rope until it flew away; if it couldn't, it meant that it was weak and had no chance of survival.

\section{Breeding Facility}

The breeding facility had a rectangular ground plan (width $30 \mathrm{~m}$, length $40 \mathrm{~m}$ and height $3 \mathrm{~m}$ ). It served as a living space for the butterfly imagoes. Live flowers and artificial feeders were used to feed the butterflies. Average temperature in the breeding area was $22-25^{\circ} \mathrm{C}$, which was $3^{\circ} \mathrm{C}$ lower than the outdoor temperature, and the relative humidity ranged from 65 to $75 \%$, which was achieved by spraying water on live plants several times a day. The air exchange took place by means of ventilation so that the air flow did not exceed $0.25 \mathrm{~m} . \mathrm{s}^{-1}$. The light intensity in the entire area was $200 \mathrm{Lx}$, at the feeders additional light sources were used to increase it to $400 \mathrm{Lx}$. Lights were turned on for 12 hour periods during which the butterflies were flying, looking for food and resting at night, when they were turned off. Shallow plastic bowls with a diameter of $20 \mathrm{~cm}$ were placed in a well-lit, easily accessible place as feeders. Overripe juicy fruits such as citrus fruits, melon, pears, 
plums, strawberries, and bananas were used as food. In addition to fruit, commercially available nectar was also offered, it was powder nectar mixed with water and served in containers. It was located near the ropes, where freshly emerged imagoes were placed, and acted as the first energy source for young butterflies capable of flight. Plants were mainly used for shelter and rest. In between the plants ropes were hung for the freshly emerged imagoes, taken from the rearing facility, to dry their wings. This ensured that each individual had as much time, as it needed to get ready for its first flight. The aim was to have the highest amount of healthy and flight-capable imagoes emerging.

\section{Data Analysis and Statistical Processing}

The obtained results consisted of healthy and damaged imagoes that emerged and chrysalises containing dead butterflies from the total number of chrysalises in each fixation type. Temperature and humidity were recorded in the morning, at noon and in the evening inside the rearing facility so the optimum environmental conditions for the developing chrysalises were maintained. The results were processed into tables in Microsoft Office Excel 2007 and the data were then statistically analyzed in Statistica 8 and SAS University Edition [14, 15].

Percentage evaluation of different fixation methods from best to least effective was made in Microsoft Office Excel 2007. Statistical significance of the results obtained was calculated with a linear ANOVA model using the ratios of healthy, damaged and dead butterflies to the total number of chrysalises in each fixation method for all the species together and for individual species separately. Tabular evaluation of statistical evidence was created with T-test.

\section{Results and Discussion}

Fixation of chrysalises is one of the most important stages of successful breeding of butterflies in artificial conditions, as it is necessary to produce a large number of individuals in a small space. For this reason, it is necessary to look for methods that are feasible and suitable for both butterflies and operators of butterfly farms.

The total number of observed chrysalises of the giant owl was 684 pieces and of the common morpho it was 754 pieces, these were included in all of the seven fixations. The total number of observed chrysalises of the indian oakleaf was 200 pieces, these were present in only four fixations due to unavailability (Table 1).

Table 2 shows the amount of healthy and damaged butterflies that emerged, and the amount of dead chrysalises of selected butterfly species throughout the research period and the effectiveness of each fixation method. The percentage and ratio of individuals to total chrysalises during each fixation is shown. Bold lettering
Table 1. Delivery dates and the amount of individual chrysalises from each species delivered.

\begin{tabular}{|c|c|c|c|}
\hline $\begin{array}{c}\text { Delivery } \\
\text { date }\end{array}$ & $\begin{array}{c}\text { Caligo } \\
\text { memnon }\end{array}$ & $\begin{array}{c}\text { Morpho } \\
\text { peleides }\end{array}$ & $\begin{array}{c}\text { Kallima } \\
\text { inachus }\end{array}$ \\
\hline 7.7 .2017 & 119 & 120 & 55 \\
\hline 21.7 .2017 & 117 & 128 & 52 \\
\hline 27.7 .2017 & 87 & 73 & 0 \\
\hline 3.8 .2017 & 142 & 138 & 0 \\
\hline 11.8 .2017 & 62 & 134 & 38 \\
\hline 17.8 .2017 & 91 & 94 & 0 \\
\hline 24.8 .2017 & 66 & 67 & 55 \\
\hline Total & 684 & 754 & 200 \\
\hline
\end{tabular}

shows the percentage and ratio of the total number of individuals to the total number of chrysalises fixed during the entire study by every single fixation method. The results show that all three butterfly species showed similar values depending on the efficiency of fixation in each individual method. Effectiveness of each fixation method is indicated by the ratio of healthy, damaged and dead butterflies to the total number of chrysalises (Table 3). It can be stated that in terms of the percentage of healthy, damaged and dead butterflies, sparse fixation for all three species was better than dense fixation. With lower fixation, there are fewer losses compared to the upper fixation. For this reason, the best method is the low sparse fixation.

The results show that the upper dense fixation had 74\% Caligo memnon, 77\% Morpho peleides and 72\% Kallima inachus successful emergence rate of healthy living viable butterflies. The losses were $26 \%, 23 \%$, $28 \%$ respectively. Advantages of this fixing method include the fact that it is possible to have a large number of chrysalises in a small space. On the other hand, a large concentration of chrysalises close together increases the risk of transfer of parasites and bacteria between each other. Butterflies usually emerge in higher numbers at once, meaning that a larger number of individuals emerge in a relatively short time one after another. This implies another negative factor, an increased number of injuries. When individuals emerge, they try to grab onto something as quickly as possible so that they can begin to dry their wings. They often hang onto one another, causing them to fall down and to tear wings of other individuals. Based on the high significant results of statistical tests and self-observation this method of fixing is classified as least effective.

Lower dense fixation had 80\% Caligo memnon, $86 \%$ Morpho peleides, and 78\% Kallima inachus successful emergence rate of healthy living viable butterflies. The losses were $20 \%, 14 \%, 22 \%$ respectively. Advantage was that there was a larger amount of individuals in the shower box in a more natural hanging position of the chrysalis on a slat. While emerging, the butterfly 
Table 2. Percentage evaluation of effectivity of different methods of fixation for all individual species.

\begin{tabular}{|c|c|c|c|c|}
\hline & Healthy & Damaged & Total emerged & Not emerged (dead) \\
\hline \multicolumn{5}{|c|}{ Caligo Memnon } \\
\hline Upper fixation - dense & $231 / 313(74 \%)$ & $50 / 313(16 \%)$ & $281 / 313(90 \%)$ & $32 / 313(10 \%)$ \\
\hline Upper fixation - sparse & $115 / 138(83 \%)$ & 18/138 (13\%) & $133 / 138(96 \%)$ & $5 / 138(4 \%)$ \\
\hline Lower fixation - dense & $100 / 125(80 \%)$ & $13 / 125(10.4 \%)$ & $113 / 125(90.4 \%)$ & $12 / 125(9.6 \%)$ \\
\hline Lower fixation - sparse & 107/108 (99\%) & 0/108 (0\%) & 107/108 (99\%) & $1 / 108(1 \%)$ \\
\hline \multicolumn{5}{|c|}{ Morpho peleides } \\
\hline Upper fixation - dense & $168 / 218(77 \%)$ & $36 / 218(16.5) \%$ & 204/218 (93,5\%) & $14 / 2186,5 \%$ \\
\hline Upper fixation - sparse & $161 / 181(89 \%)$ & 20/181 (11\%) & 181/181 (100\%) & $0 / 181(0 \%)$ \\
\hline Lower fixation - dense & $176 / 20586 \%$ & $17 / 205(8 \%)$ & 193/205 (94\%) & $12 / 205(6 \%)$ \\
\hline Lower fixation - sparse & $150 / 150(100 \%)$ & $0 / 150(0 \%)$ & $150 / 150(100 \%)$ & $0 / 150(0 \%)$ \\
\hline \multicolumn{5}{|c|}{ Kallima inachus } \\
\hline Upper fixation - dense & $60 / 83(72 \%)$ & $15 / 83(18 \%)$ & 75/83 (90\%) & $8 / 83(10 \%)$ \\
\hline Upper fixation - sparse & $31 / 36(86 \%)$ & $5 / 36(14 \%)$ & $36 / 36(100 \%)$ & $0 / 36(0 \%)$ \\
\hline Lower fixation - dense & $35 / 45(78 \%)$ & $6 / 45(78 \%)$ & $41 / 45(91 \%)$ & $4 / 45(9 \%)$ \\
\hline Lower fixation - sparse & $36 / 36(100 \%)$ & $0 / 36(0 \%)$ & $36 / 36(100 \%)$ & $0 / 36(0 \%)$ \\
\hline
\end{tabular}

catches on the chrysalis walls that hang from a slat, or a lower edge of the slat more easily. For this reason, losses were lower. Our results correspond with the data of [12] from the Botanical Garden in Košice, who stated that they had recorded $80 \%$ success rate of healthy evolved individuals in eight years, using this fixation method. Based on high significant results of statistical tests and self-observation this method of fixing is ranked third in terms of the effectiveness of fixing the pupae of butterflies.

The lower sparse fixation had $83 \%$ Caligo memnon, $89 \%$ Morpho peleides and $86 \%$ Kallima inachus successful emergence rate of healthy living viable butterflies. Losses were $17 \%, 11 \%, 14 \%$ respectively. The advantages of this method of fixing include reduced risk of transmitting parasites or bacterial diseases from one chrysalis to another, because they are further apart and are less numerous. Disadvantages include the fact that, while emerging, the butterfly must exert greater effort to grab on to the upper edge of the slat. Based on high significant results of statistical tests and selfobservation this method of fixation ranks second in terms of the effectiveness of the fixation of butterfly chrysalises.

The lower sparse fixation had 99\% Caligo memnon, 100\% Morpho peleides and 100\% Kallima inachus successful emergence rate of healthy living viable butterflies. Losses were $1 \%, 0 \%, 0 \%$ respectively. Lower concentrations of chrysalises on each slat and greater space between them reduce the risk of transmission of bacterial diseases and parasites. The butterfly easily grabs on to the lower edge of a slat and remains attached. Based on high significant results of statistical tests and self-observation this method of fixing the butterfly chrysalises is evaluated as the most effective of the tested methods.

Figs 3 and 4 show that the ratio of healthy emerged butterflies to the total number of chrysalises has an increasing tendency in the direction of upper dense - lower dense - upper sparse - lower sparse (from the least efficient to the most efficient fixation method). The ratio of damaged butterflies to the total number of chrysalises has a decreasing tendency, confirming the effectiveness of each method, and the ratio of the dead

Table 3. Fixation type and total amount of healthy or damaged imagoes and dead butterflies.

\begin{tabular}{|c|c|c|c|c|c|c|c|c|c|c|c|c|}
\hline Fixation & \multicolumn{3}{|c|}{ Upper fixation - dense } & \multicolumn{2}{c|}{ Upper fixation - sparse } & \multicolumn{2}{c|}{ Lower fixation - dense } & \multicolumn{3}{c|}{ Lower fixation - sparse } \\
\hline Species & Healthy & Damaged & Dead & Healthy & Damaged & Dead & Healthy & Damaged & Dead & Healthy & Damaged & Dead \\
\hline Caligo memnon & 231 & 50 & 32 & 115 & 18 & 5 & 100 & 13 & 12 & 107 & 0 & 1 \\
\hline Morpho peleides & 168 & 36 & 14 & 161 & 20 & 0 & 176 & 17 & 12 & 150 & 0 & 0 \\
\hline Kallima inachus & 60 & 15 & 8 & 31 & 5 & 0 & 35 & 6 & 4 & 36 & 0 & 0 \\
\hline
\end{tabular}



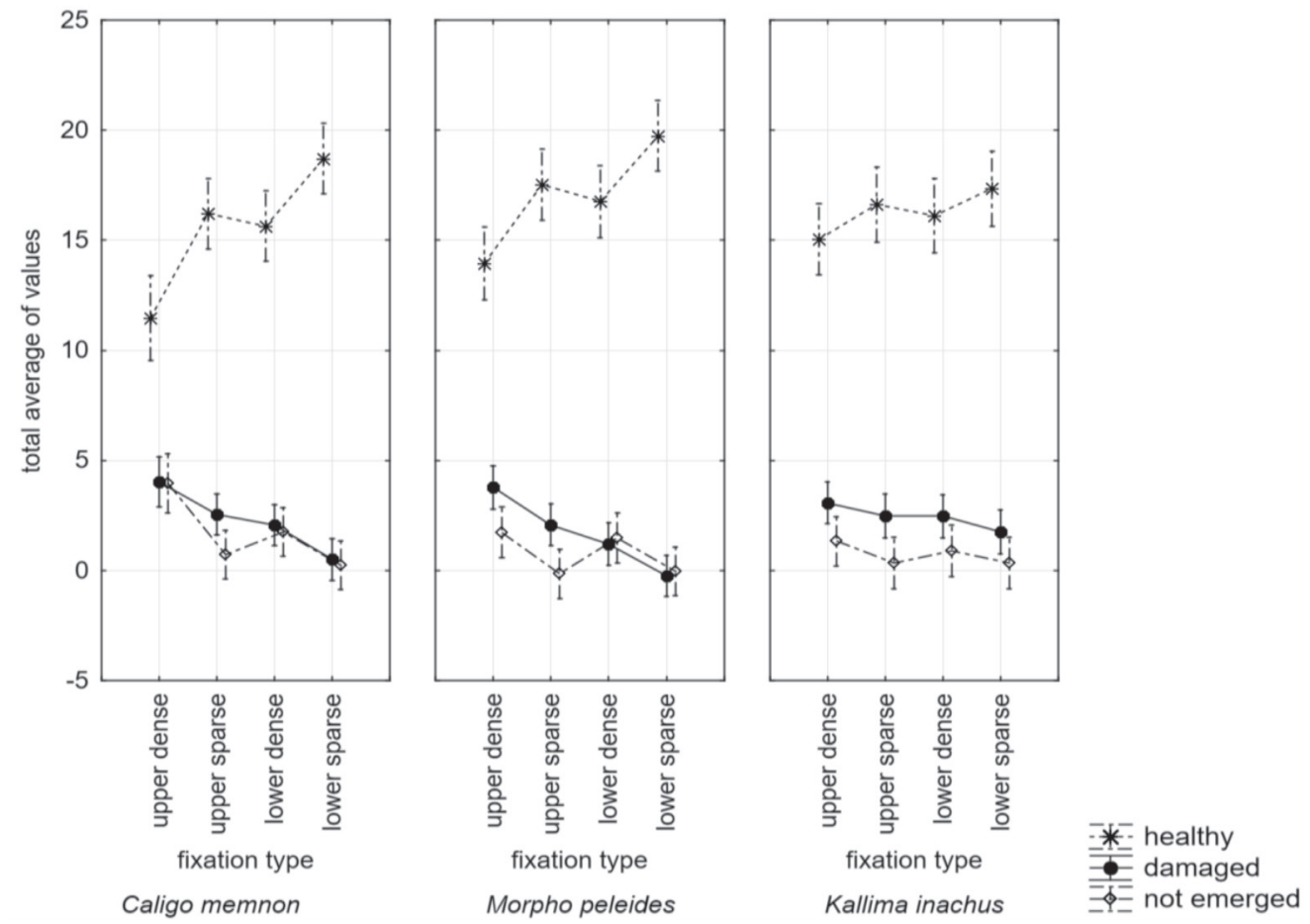

Fig. 3. Statistical significance within species (ANOVA, Wilks lambda $=0,47557, F=11,852, p=0,00000$ ): ratio of healthy, damaged emerged and dead butterflies to the total number of chrysalises.

butterflies to the total number of chrysalises proves that the denser fixation of the chrysalises leads to higher rates of dead individuals.

The difference of the ratio of healthy and damaged butterflies to the total number of chrysalises is highly statistically significant $(\mathrm{p}<0.001)$.

The difference of the ratio of healthy and damaged butterflies to the total number of chrysalises is highly statistically significant $(\mathrm{p}<0.001)$ for each fixation method.

There are two known reasons for the death of a butterfly inside a chrysalis. One of the reasons is of genetic causes that cannot be influenced. It is caused by genetic factors and anomalies arising during transformation of a caterpillar into a butterfly inside a chrysalis. The second cause is death due to bacterial

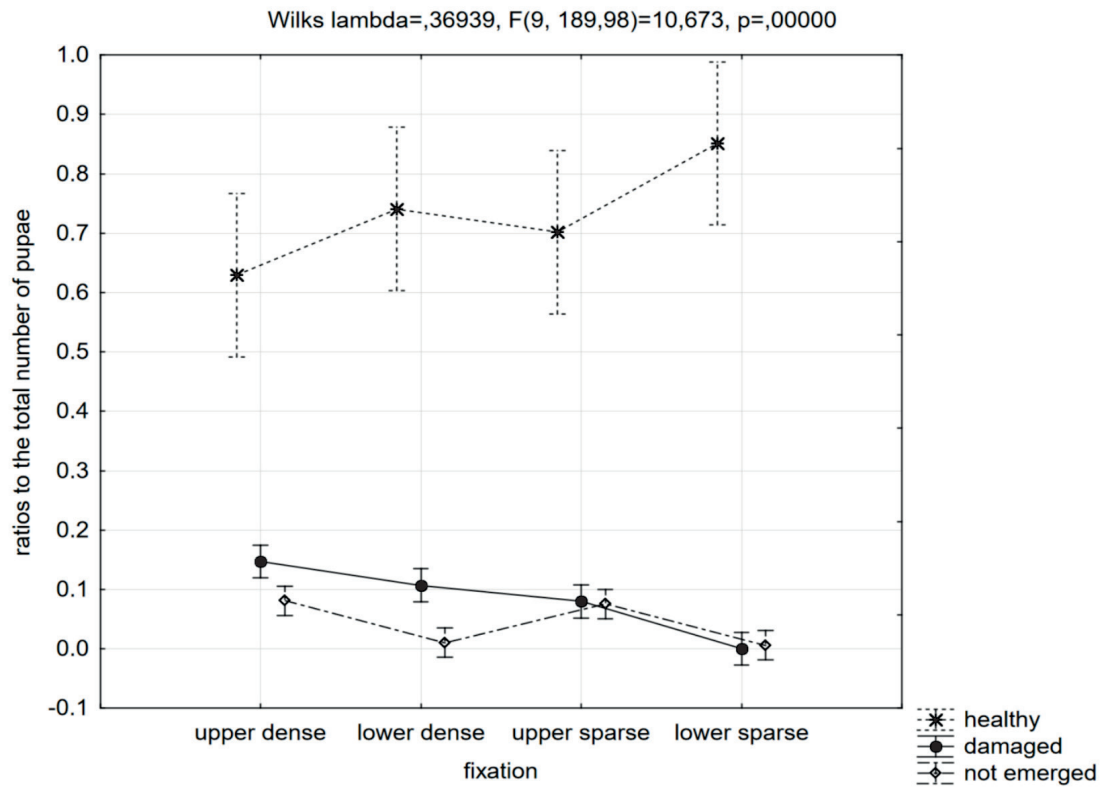

Fig. 4. Statistical significance (ANOVA, Wilks lambda $=0.36939, \mathrm{~F}=10.637, \mathrm{p}=0.00000$ ): ratio of healthy, damaged emerged and dead butterflies to the total number of chrysalises. 
Table 4. Statistical significance of ratios of healthy and damaged emerged butterflies to the total number of chrysalises.

\begin{tabular}{|l|r|c|c|c|c|c|c|r|r|r|}
\hline \multirow{2}{*}{ Variable } & \multicolumn{7}{|c|}{ All Groupes T-test for dependent Samples. Marked duffereces are significant at $p<0.05000$} \\
\cline { 2 - 11 } & Mean & Std.Dv. & $\mathrm{N}$ & Diff. & Std.Dv.Diff. & $\mathrm{t}$ & $\mathrm{df}$ & $\mathrm{p}$ & $\begin{array}{c}\text { Confidence - } \\
95.000 \%\end{array}$ & $\begin{array}{c}\text { Confidence } \\
+95.000 \%\end{array}$ \\
\hline ratio healthy v total & 0.73064 & 0.32065 & & & & & & & & \\
\hline ratio damaged v total & 0.08335 & 0.08314 & 84 & 0.647290 & 0.321942 & 18.4273 & 83 & 0.00 & 0.577425 & 0.717156 \\
\hline
\end{tabular}

Table 5. Statistical significance of the difference between the ratio of healthy and damaged butterflies to the total number of chrysalises in each fixation method separately.

\begin{tabular}{|c|c|c|c|c|c|c|c|c|c|c|c|}
\hline \multirow[t]{2}{*}{ Variable } & \multicolumn{11}{|c|}{ Aggregate Results T-test for Dependent Samples. Marked duffereces are significant at $\mathrm{p}<0.05000$} \\
\hline & Fixation & Mean & Std.Dv. & $\mathrm{N}$ & Diff. & std.Dv.Diff & $\mathrm{t}$ & df & $\mathrm{p}$ & \begin{tabular}{|c|} 
Confidence - \\
$95.000 \%$ \\
\end{tabular} & $\begin{array}{c}\text { Confidence } \\
+95.000 \%\end{array}$ \\
\hline ratio $\mathrm{h} / \mathrm{t}$ & ud & 0.629093 & 0.279595 & & & & & & & & \\
\hline ratio $d / t$ & ud & 0.146967 & 0.090733 & 21 & 0.482125 & 0.252560 & 8.747923 & 20 & 0.000000 & 0.367161 & 0.597089 \\
\hline ratio $\mathrm{h} / \mathrm{t}$ & us & 0.740764 & 0.318737 & & & & & & & & \\
\hline ratio $\mathrm{d} / \mathrm{t}$ & us & 0.106459 & 0.061211 & 21 & 0.634305 & 0.288130 & 10.08835 & 20 & 0.000000 & 0.503150 & 0.765460 \\
\hline ratio $\mathrm{h} / \mathrm{t}$ & Id & 0.701519 & 0.303816 & & & & & & & & \\
\hline ratio $d / t$ & Id & 0.079978 & 0.067770 & 21 & 0.621541 & 0.287452 & 9.908641 & 20 & 0.000000 & 0.490695 & 0.752388 \\
\hline ratio $\mathrm{h} / \mathrm{t}$ & Is & 0.85119 & 0.357113 & & & & & & & & \\
\hline ratio $d / t$ & Is & 0.000000 & 0.000000 & 21 & 0.85119 & 0.357113 & 10.92272 & 20 & 0.000000 & 0.688635 & 10.013746 \\
\hline
\end{tabular}

Table 6. Correlation between the ratios of healthy and damaged butterflies to the total number of chrysalises for each fixation method.

\begin{tabular}{|c|c|c|c|c|c|c|c|c|c|c|c|c|}
\hline \multirow{2}{*}{ Group 1 vs. Group 2} & \multicolumn{12}{|c|}{ Aggregate Results T-test for Independent Samples. Note: Variables were treated as independent samples } \\
\hline & Fixation & $\begin{array}{c}\text { Mean } \\
\text { Group 1 }\end{array}$ & \begin{tabular}{|c|} 
Mean \\
Group 2
\end{tabular} & t-value & $\mathrm{df}$ & $\mathrm{p}$ & $\begin{array}{l}\text { Valid N } \\
\text { Group 1 }\end{array}$ & \begin{tabular}{|l|} 
Valid N \\
Group 2
\end{tabular} & $\begin{array}{l}\text { Std.Dev. } \\
\text { Group } 1\end{array}$ & $\begin{array}{l}\text { Std.Dev. } \\
\text { Group } 2\end{array}$ & $\begin{array}{l}\text { F-ratio } \\
\text { Variances }\end{array}$ & $\mid \begin{array}{c}\mathrm{p} \\
\text { Variances }\end{array}$ \\
\hline ratio $h / t$ vs. ratio $d / t$ & ud & 0.629093 & 0.146967 & 7.516204 & 40 & 0.000000 & 21 & 21 & 0.279595 & 0.090733 & 9.495723 & 0.000005 \\
\hline ratio $\mathrm{h} / \mathrm{t}$ & us & 0.740764 & 0.106459 & 8.955926 & 40 & 0.000000 & 21 & 21 & 0.318737 & 0.061211 & 27.11523 & 0.000000 \\
\hline ratio $\mathrm{h} / \mathrm{t}$ & Id & 0.701519 & \begin{tabular}{|l|}
0.079978 \\
\end{tabular} & 9.150079 & 40 & 0.000000 & 21 & 21 & 0.303816 & 0.067770 & 20.09793 & 0.000000 \\
\hline ratio $\mathrm{h} / \mathrm{t}$ & Is & 0.851190 & \begin{tabular}{|l|}
0.00 \\
\end{tabular} & 10.92272 & 40 & 0.000000 & 21 & 21 & 0.357113 & 0.00 & 0.00 & 1.000000 \\
\hline
\end{tabular}

disease or parasites [16, 17]. Using the dense fixation methods there were more dead chrysalises on slats, than using the sparse methods. This was influenced by a higher number of individuals close to each other and thus a higher probability of pathogen transfer. Bacteria spread faster from one chrysalis to another, when they are in high density close side by side. According to [18], chrysalises are susceptible to various infections and diseases. When one of them is infected in one breeding area, this usually leads to the death of more chrysalises in the same area.

Our results correlate with the data of [19], who evaluated the lower sparse fixation method as the best. It states that the losses of the chrysalises are minimal (about $5 \%$ ) and are mainly caused by predators (ants) that got through the mesh to the rearing facility.

Based on the obtained results, we found that the upper sparse fixation method is the second best alternative. Its success rate among the studied species was $83 \%, 89 \%, 86 \%$ respectively.

In a butterfly garden in England, which is part of the London Zoo, the lower dense fixation method was used with chrysalises, showing $20 \%$ losses and a success rate of $80 \%$. In our case the success rate of fixation among the observed species was $80 \%, 86 \%, 78 \%$ respectively. At the Butterfly Farm in Stratford Upon Avon, where the chrysalises were also bought from, they were fixed to sticks with Copydex glue using the lower dense and the lower sparse methods. Losses at the lower dense fixation method represent $18 \%$ and with the lower sparse method were $10 \%$ maximum [20].

In comparison of our results with the other butterfly breeding organizations, it is apparent that when using the methods of fixation with lower or hanging positions of the chrysalises, there are lower losses. From an economic point of view, dense fixation methods are used to place a large number of chrysalises inside a small space. The upper or lower method of fixation of the chrysalis also depends on whether they are glued to a wooden slat or a branch.

Temperature and photoperiod also had a significant effect on larval development, which is confirmed by other authors [21-25]. [26-28] state that photoperiod and temperature play a role in the larval development and survival rate of the larvae of $K$. inachus. Photoperiods affect the development period of larvae at $20^{\circ} \mathrm{C}$ but not at $25^{\circ} \mathrm{C}$ and at $30^{\circ} \mathrm{C}$. As the temperature increased from $20^{\circ} \mathrm{C}$ to $25^{\circ} \mathrm{C}$ and to $30^{\circ} \mathrm{C}$, the developmental periods 
of larvae reduced under the same photoperiod from 31.7 to 36.0 days, from 26.37 to 27.4 days and from 21.0 to 21.5 days, respectively. Increasing the temperature also made an increase in the survival rate under different photoperiods. The survival rate of larvae at $20^{\circ} \mathrm{C}, 25^{\circ} \mathrm{C}$, and $30^{\circ} \mathrm{C}$ was $80 \%-92 \%, 75 \%-95 \%$, and $55 \%-85 \%$, respectively. While there are more advantages with higher pupal density in nature [24], it might not be as advantageous in captivity.

\section{Conclusion}

The research of various fixation methods of chrysalises of selected butterfly species was focused on finding the most effective method of fixation of a butterfly chrysalis on wooden slats, testing four different widely used methods. These results can be applied in zoos and other institutions that breed butterflies. Statistically, the lower sparse fixation method was the best. Its main drawback is that it is not possible to have a large number of chrysalises in one hatchery. The highest losses were recorded using the dense methods. If we consider the economic aspect of intensive breeding conditions, where the main criterion is the production of as many individuals as possible, we would recommend a lower dense fixation method. For each method of fixation, it is necessary to ensure the optimal temperature and humidity in the hatchery, sufficient food for the emerged individuals and minimizing losses caused by predators and pathogens.

\section{Acknowledgments}

This research was supported by the grant project VEGA 1/0604/20 „Environmental Assessment of Specific Biotopes of Danubian Lowland".

\section{Conflict of Interest}

The authors declare no conflicts of interest.

\section{References}

1. KHYADE V.B., JAGTAP S.G. Diversity of butterflies (Order: Lepidoptera) in Mayureshwar Wildlife Sanctuary of Baramati Tehsil Dist. Pune (India). International Academic Journal of Innovative Research, 3 (11), 40, 2016.

2. ZHANG W., SHIH C., REN D. Lepidoptera - Butterflies and Moths. Rhythms of Insect Evolution, 619-630, 2019

3. FRANC V. System and phylogeny of animals invertebrates. Banska Bystrica, 169, 2005.

4. FRANC V. System and phylogeny of animals invertebrates. Banska Bystrica, 184, 2007.

5. HOSKINS A. Butterflies of the World. New Holland Publishers, 352, 2015.

6. MORGAN S. The World Encyclopedia of Butterflies \& Moths A Natural History and Identification Guide to
Over 565 Varieties Around the Globe, Lorenz Books, 256, 2019.

7. HANSKI I. SAASTAMOINEN M., OVASKAINEN O., Dispersal-related life-history trade-offs in a butterfly metapopulation. Journal of Animal Ecology, 75, 91, 2006.

8. HANSKI I. Eco-evolutionary spatial dynamics in the Glanville fritillary butterfly. Proceedings of the National Academy of Sciences, USA, 108, 14397, 2011.

9. IABES. Member facilities. St Paul, MN: Interna-tional Association of Butterfly Exhibitors and Suppliers, 2015.

10. VELTMAN K. How can Zoos import and display butterflies for educational purposes in a sustainable way? International Zoo Yearbook, 43, 124, 2009.

11. SAUL-GERSHENZ L. Insect zoos. Encyclopedia of insects, $2^{\text {nd }}$ ed., Academic Press, 516, 2009.

12. SUVÁK M. Exotic butterflies and moths (Lepidoptera) in botanical gardens- potential for education and research. Thaiszia-J. Bot., 25 (1), 81, 2015.

13. PUTRI I. Handicraft of butterflies and moths (Insecta: Lepidoptera) in Bantimurung Nature Recreation Park and its implications on conservation. Biodiversitas, Journal of Biological Diversity, 17, 823, 2016.

14. Statistica 8. Software system for data analysis. www. statSoft.cz.

15. SAS University Edition

16. MYERS J.H., CORY J.S. Ecology and evolution of pathogens in natural populations of Lepidoptera. Evolutionary applications, 9, 231, 2016.

17. BRABY M.F., FRANKLIN D.C., BISA D.E., WILLIAMS M.R., WILLIAMS A.A.E., BISHOP C.L., COPPEN R.A.M. Atlas of butterflies and diurnal moths in the monsoon tropics of Northern Australia. The Australian National University, 462, 2018.

18. LAŠTU゚VKA A., LAŠTƯVKA Z., LIŠKA J., ŠUMPRICH J. Butterflies and caterpillars of Central Europe V. Small butterflies I. Academia Prague, 536, 2018.

19. HARBERD R.A Manual of Tropical Butterfly Farming. B. $\mathrm{m}$. The Darwin Initiative, 35, 2005.

20. STRATFORD-upon-Avon butterfly farm. https://www. butterflyfarm.co.uk/, 2017.

21. KODA K., NAKAMURA H. Effects of temperature on the development and survival of an endangered butterfly, Shijimiaeoides divinus barine (Leech) (Lepidoptera: Lycaenidae). Entomological Science, 13 (1), 29, 2010.

22. YANG F., HU G., SHI J.J, ZHAI B.P. Effects of larval density and food stress on life-history traits of Cnaphalocrocis medinalis (Lepidoptera: Pyralidae). Journal of Applied Entomology, 139 (5), 370, 2014.

23. KRECHEMER F.S., FOERSTER L.A. Tuta absoluta (Lepidoptera: Gelechiidae): Thermal requirements and effect of temperature on development, survival, reproduction and longevity. European Journal of Entomology, 112 (4), 658, 2015.

24. SAKAMOTO Y., HIRAI N., ISHII M. Effects of photoperiod and temperature on the development and diapause of the endangered butterfly Zizina emelina (Lepidoptera: Lycaenidae). Journal of Insect Conservation, 19 (4), 639, 2015

25. TANG J., CHENG Y., SAPPINGTON T.W., JIANG X., ZHANG L., LUO L. Egg Hatch and Survival and Development of Beet Webworm (Lepidoptera: Crambidae) Larvae at Different Combinations of Temperature and Relative Humidity. Journal of Economic Entomology, 109 (4), 1603, 2016. 
26. KHYADE V.B. Camouflage the Dead - Leaf Butterfly, Kallima inachus (L). International Academic Journal of Innovative Research, 3 (12), 13, 2016.

27. KHYADE V.B., JAGTAP S.G. Butterflies - Diversity in Mayureshwar Wildlife Sanctuary of Baramati Tehsil in Pune district (India). Journal of Entomology and Zoology Studies, 5 (2), 443, 2017.

28. VAN SWAAY C.A.M., DENNIS E.B., SCHMUCKI R., SEVILLEJA C., BALALAIKINS M., BOTHAM M., BOURN N., BRERETON T., CANCELA J.P., CARLISLE B., CHAMBERS P., COLLINS S., DOPAGNE, C., ESCOBÉS R., FELDMANN R., FERNÁNDEZ-GARCÍA J.M., FONTAINE B., GRACIANTEPARALUCETA A., HARROWER C., HARPKE A., HELIÖLÄ J., KOMAC
B., KÜHN E., LANG A., MAES D., MESTDAGH X., MIDDLEBROOK I., MONASTERIO Y., MUNGUIRA M.L., MURRAY T.E., MUSCHE M., ÕUNAP E., PARAMO F., PETTERSSON L.B., PIQUERAY J., SETTELE J., STEFANESCU C., ŠVITRA G., TIITSAAR A., VEROVNIK R., WARREN M.S., WYNHOFF I., ROY D.B. The EU Butterfly Indicator for Grassland species: 1990-2017. Technical Report. Butterfly Conservation Europe \& ABLE/eBMS, 23, 2019.

29. BONSIGNORE C.P., MANTI F., CASTIGLIONE E., BATTISTI A. Pupal traits and adult emergence in the pine processionary moth Thaumetopoea pityocampa (Lepidoptera: Notodontidae) are affected by pupal density. European Journal of Entomology, 116, 320, 2019. 